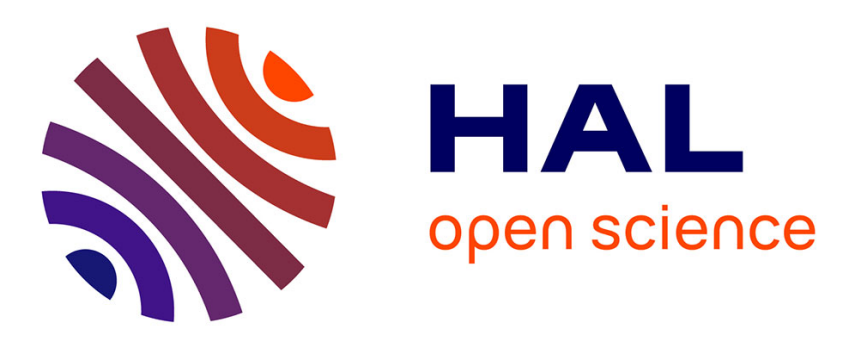

\title{
Light and temperature influence on diuron bioaccumulation and toxicity in biofilms
}

Betty Chaumet, Nicolas Mazzella, Julie Neury-Ormanni, Soizic Morin

\section{To cite this version:}

Betty Chaumet, Nicolas Mazzella, Julie Neury-Ormanni, Soizic Morin. Light and temperature influence on diuron bioaccumulation and toxicity in biofilms. Ecotoxicology, 2020, 29, pp.185-195. 10.1007/s10646-020-02166-8 . hal-02610164

\section{HAL Id: hal-02610164 \\ https://hal.inrae.fr/hal-02610164}

Submitted on 11 Apr 2021

HAL is a multi-disciplinary open access archive for the deposit and dissemination of scientific research documents, whether they are published or not. The documents may come from teaching and research institutions in France or abroad, or from public or private research centers.
L'archive ouverte pluridisciplinaire HAL, est destinée au dépôt et à la diffusion de documents scientifiques de niveau recherche, publiés ou non, émanant des établissements d'enseignement et de recherche français ou étrangers, des laboratoires publics ou privés. 
Cedex, France

\section{Abstract}

9 Variations of temperature and photoperiod throughout different seasons can affect aquatic communities such as biofilms. Biofilms, generally present at the base of trophic chains in freshwaters, are also subject to organic contamination, and are especially affected by herbicides. Many studies have investigated the effect and interactions of herbicides and environmental factors on biofilms, but never with a toxicokinetic point of view.

The objective of this study was to assess structural and functional changes in biofilms exposed to diuron, and to link them with contaminant accumulation, under the influence of temperature and light variations. To this aim, biofilms were exposed to all possible combinations of three concentrations $\left(0,5\right.$ and $\left.50 \mu \mathrm{g} \cdot \mathrm{L}^{-1}\right)$ of diuron, two temperatures $\left(10\right.$ and $\left.26^{\circ} \mathrm{C}\right)$, and two light/dark photoperiods $(16 / 8,10 / 14)$, for durations of 0,1 and 3 days. Diuron accumulation in biofilms was quantified and structural descriptors (protein and polysaccharide contents, dry weight) and functional endpoints (photosynthetic and enzymatic activities) were analysed. The results obtained mainly highlighted the influence of temperature on diuron bioaccumulation and the associated toxic impact on biofilms. Bioaccumulation in biofilms exposed during three days at $10^{\circ} \mathrm{C}$, at the highest diuron concentration, was in average 1.4 times higher than bioaccumulation on 
biofilms exposed to $26^{\circ} \mathrm{C}$. Accordingly, the photosynthetic yield was more inhibited at lower than at higher temperatures. Temperature was also the highest impacting factor for metabolism regulation; for example, at $26^{\circ} \mathrm{C}$ after three days of exposure, polysaccharide production was boosted under both photoperiods tested.

\section{Keywords}

Freshwater periphyton, herbicide, microbial ecotoxicology, seasons, toxicokinetics-toxicodynamics

\section{Introduction}

It is well known that temperature and incident light are two of the main environmental factors able to modulate primary production (Dodds et al., 1996; Gomes \& Juneau, 2017; Staehr \& Sand-Jensen, 2006). In temperate regions, both factors change seasonally, subjecting primary production to seasonal variations. Temperature and photoperiod influence organisms at the base of trophic chains in aquatic environments such as biofilms (Flemming et al., 2007) which are composed of microalgae, fungi and bacteria embedded in an EPS matrix (Aguilera et al., 2008; Flemming \& Wingender, 2010). The EPS matrix contains polysaccharides, which make-up around $97 \%$ of its total constituents (Aguilera et al., 2008), proteins, humic acids and DNA. Additionally, biofilm integrates and reacts quickly to contamination, making it a good bioindicator (Edwards \& Kjellerup, 2013).

Biofilms are increasingly constrained by environmental stresses, coupled with anthropogenic pressures such as organic pollution (DeLorenzo et al., 2001; Guasch et al., 2016; Kim Tiam et al., 2016). In fact, watercourses are among the final receptacles of pollution, including pesticide contamination brought about by runoff or leaching processes (Kohusova et al., 2011). Due to their massive use, pesticides are widely monitored in aquatic environments. This is especially true for diuron, a photosynthesis inhibitor of photosystem II herbicide (Yebra et al., 2004), considered as a priority substance in the European Water Framework Directive (Directive 2000/06/EC). Herbicides, 
and diuron in particular, have been shown to drastically reduce photosynthetic activity (Kim Tiam et al., 2015; Pesce et al., 2011; Tlili et al., 2008).

Many studies have already tackled the biological impacts of temperature, light and herbicide contamination on biofilm (e.g: Bérard et al., 1999; Larras et al., 2013; Villeneuve et al., 2010). The effects of these parameters on the growth and photosynthetic efficiency of autotrophic organisms are well documented. In fact, it has already been shown that an increase in temperature, or in the length of the photoperiod can increase biofilm resistance to contaminants (Staehr \& Sand-Jensen, 2006; Herzig \& Dubinsky, 1992). Moreover, Duong et al. (2010) and Villeneuve et al. (2011) showed that biofilm community composition could be modified according to season. Also, Wolfstein \& Stal (2002) highlighted a variation in EPS content associated with different temperatures and degrees of irradiance exposure. Also, Chalifour et al. (2014) showed that temperature can affect the sensitivity of biofilms to herbicides.

According to the literature, a biofilm exposed to high temperatures, greater irradiance (such as during summer) and herbicides would be less sensitive to toxic effects than a winter biofilm (Chalifour et al., 2014). Variations of temperature and light intensity target processes involved in photosynthesis and metabolism (Guasch et al. 2016). As these environmental factors, pesticides such as herbicides can interact on photosynthesis and metabolism process due to their mode of action (Draber et al., 1991). These combined effects may be synergistic, additional or antagonistic, but remain little known.

As herbicides, light and temperature co-occur in natural environments, we can hypothesise the interaction between all these factors may disturb the normal functioning of biofilm, and potentially more during the winter period. Consequently, it is crucial to study the fate and effect of herbicides in biofilms, and their impact, under environmental factors variations.

To answer this question, the aim of this study was to use a toxicokinetic-toxicodynamic approach to gain a better understanding of the different steps related to the effect of diuron under contrasting 
seasonal conditions. Thanks to this approach, more details would be provided about the time needed for metabolism processes and variation among herbicide contamination.

The objectives of the study were to investigate i) bioaccumulation by microorganisms in the biofilm, ii) subsequent modification of photosynthetic yield, and finally, iii) overall impact on metabolism via the determination of biochemical contents, and the measurement of complementary heterotrophic enzymatic activities.

\section{Materials and methods}

To reach the objectives arising from the problematic of this study, an experimental design was set up in which a mature biofilm was exposed to a combination of two different temperatures $\left(10\right.$ and $\left.26^{\circ} \mathrm{C}\right)$ and photoperiods (light/dark: $16 / 8$ and 10/14), and to three diuron concentrations (0, 5 and $50 \mu \mathrm{g} . \mathrm{L}^{-}$ $\left.{ }^{1}\right)$.

\subsection{Experimental design}

During January-February 2017, bare glass slides (L: $26 \mathrm{~cm}$, I: $6 \mathrm{~cm}$ ) were placed in Gazinet-Cestas pond (South-West France, geographical coordinates: $44^{\circ} 46^{\prime} 30.1^{\prime \prime} \mathrm{N}, 0^{\circ} 41^{\prime} 44.3^{\prime \prime} \mathrm{W}$ ). They were collected after four weeks of immersion, the time needed for biofilm to colonize the slides. During the colonization period, water temperature was $8.6 \pm 0.5{ }^{\circ} \mathrm{C}(n=9)$, and daily hours of sunlight numbered $10 h 09 \pm 6 \min (n=50)$.

The collected biofilm was immediately re-immersed in artificial channels $(\mathrm{L}: 50 \mathrm{~cm}, \mathrm{I}: 9.2 \mathrm{~cm}, \mathrm{H}$ : $5 \mathrm{~cm}$ ) containing recirculating dauta medium (Dauta, 1982) at a pH of 7.5-8, with a flow velocity of 2 $\mathrm{cm} . \mathrm{s}^{-1}$, in a thermoregulated room. Two temperatures were tested, with room temperature set at $26^{\circ} \mathrm{C}$ and $10^{\circ} \mathrm{C}$, and for each temperature, two light/dark photoperiods were applied: $16 / 8$ and 
$10 / 14$, to mimic four contrasting "seasonal conditions" (named "Seasons" 1 to 4) as presented in Figure 1. The four experiments were performed independently, starting from Season 1 (S1) on February $13^{\text {th }}$, to Season $4(\mathrm{~S} 4)$, ending on March $9^{\text {th }}$, with one experiment per week during this period. A diuron (CAS: 330-54-1, purity: $99 \%$, Dr Ehrenstorfer GmbH) stock solution was prepared in acetonitrile (CAS: $75-05-8$, purity: $99.97 \%$, Biosolve) to reach a final concentration of $200 \mathrm{mg} . \mathrm{L}^{-1}$. The toxicity of acetonitrile was tested on biofilms prior to the experiment. The NOEC was established at $1 \%$, based on the measurement of photosynthesis inhibition (Neury-Ormanni, unpublished data). All exposure conditions were prepared to ensure that the final concentration of acetonitrile reached $0.25 \%$, which is below the established NOEC. For each condition, three nominal concentrations of diuron were selected: 0,5 and $50 \mu \mathrm{g} \cdot \mathrm{L}^{-1}$ (respectively named Ctrl, 5D and 50D, prepared from stock solution in ultrapure water), and the biofilms were exposed to these conditions during one and three days, to ensure that the equilibrium between diuron concentrations in water and in biofilms was reached (Chaumet et al., 2019). Moreover, the 3-day exposure was expected to be enough to highlight likely effects of photoperiod (16/8 photoperiod condition has $37 \%$ more hours of illumination than 10/14 photoperiod condition). 


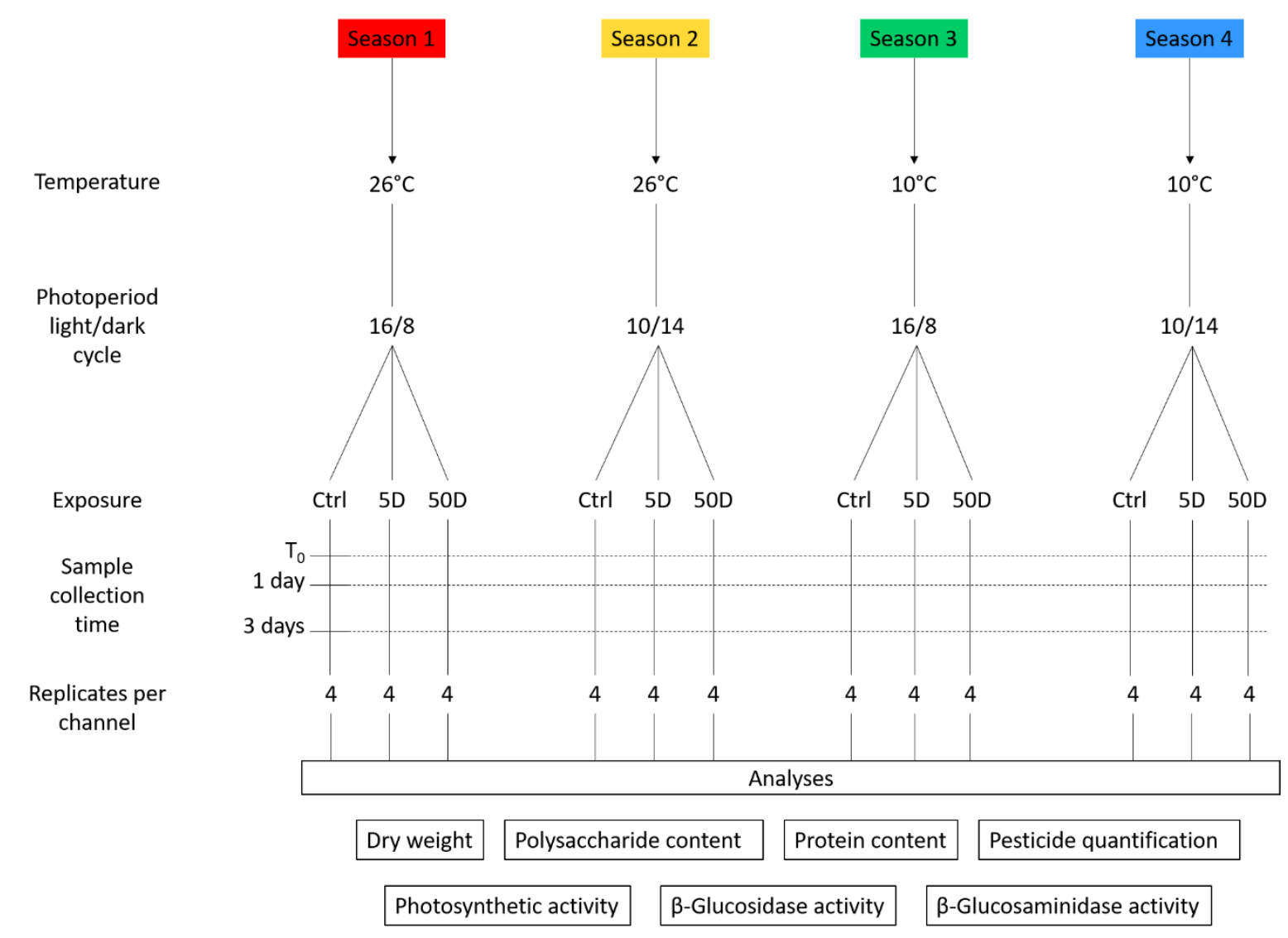

113 Figure 1: Graphical representation of experimental design and abbreviations associated with each

114 condition

117 At each collection time ( $\mathrm{T}_{0}$, one day and three days) for each condition (S1, S2, S3 and S4 for all the 118 diuron exposure: Ctrl, 5D and 50D), four replicates from the same channel were sampled and 119 prepared as described below. Biofilms were scrapped with a razor blade and introduced into a 120 beaker previously filled with $40 \mathrm{~mL}$ of dauta medium. Biofilm directly collected after colonisation in 121 the pond (i.e. without exposure in the channels) was also analysed in the same way as those after 122 one and three days of exposure and was named $\mathrm{T}_{0}$. All samples were homogenized by agitation at room temperature for 30 minutes at $150 \mathrm{rpm}$ (Variomag multi-station agitator, Thermo-Scientific). Several analyses were then performed on biofilms in suspension: determination of dry weight (2.3.2), 
polysaccharide (2.4.1) and protein content (2.4.2), enzymatic (2.4.3) and photosynthetic activities (2.4.4), and pesticide quantification (2.3.4).

\subsection{Sample processing and physicochemical analyses}

\subsubsection{Experimental conditions}

Three $\mathrm{mL}$ of water from each channel were collected at each sampling time $\left(\mathrm{T}_{0}\right.$, one day and three days) for all conditions (S1, S2, S3 and S4) and exposure conditions (the control and the two contaminated); and filtered on syringe-filters (pore: $0.45 \mu \mathrm{m}$, hydrophilic regenerated cellulose membrane, Whatman), in order to quantify pesticide content in the medium. A volume of $10 \mu \mathrm{L}$ of internal standards was added to $990 \mu \mathrm{L}$ of the filtrate prior to analysis (see 2.3.4). The solution of internal standards contained Diuron D6 (CAS: 1007536-67-5 - purity: $98 \%$, provided by Dr. Ehrenstorfer $\mathrm{GmbH}$ ) prepared at $10 \mathrm{mg} \cdot \mathrm{L}^{-1}$.

The temperature in the channels and in the thermoregulated room was measured by data loggers (Tinytag, Radiospare) every ten minutes for each condition. A light meter (LI-COR Li-250, USA) was used to control incident light intensity reaching the slides. The data are listed in Table 1.

Table 1: Mean ( \pm standard error) temperatures $(n=475)$ and light intensity $(n=8)$ during the experiments

\begin{tabular}{|c|c|c|c|}
\hline Conditions & Water temperature $\left({ }^{\circ} \mathrm{C}\right)$ & Room temperature $\left({ }^{\circ} \mathrm{C}\right)$ & Light intensity $\left(\mu \mathrm{mol} . \mathrm{s}^{-1} \cdot \mathrm{m}^{-2}\right)$ \\
\hline Season 1 & na* & na* & \\
\hline Season 2 & $22.70 \pm 0.59$ & $25.16 \pm 0.01$ & \multirow{2}{*}{$7.47 \pm 0.42$} \\
\hline Season 3 & $11.60 \pm 0.18$ & $11.23 \pm 0.00$ & \\
\hline Season 4 & $11.65 \pm 0.15$ & $11.17 \pm 0.00$ & \\
\hline
\end{tabular}


na*: data not available. A technical problem was encountered for the recording of Season 1 temperature data, but the temperature settings of the thermoregulated room were identical between Season 1 and Season 2.

\subsubsection{Dry weight}

For dry weight measurement, $8.8 \mathrm{~mL}$ of the $40 \mathrm{~mL}$ of suspended biofilm were filtered on a Buchner with previously-weighed ashed GF/F filters ( $\varnothing 90 \mathrm{~mm}$, pore size: $0.7 \mu \mathrm{m}$, Whatman). Then, filters were frozen for 12 hours, lyophilised, and re-weighed. Dry weight data were used to standardize bioaccumulation data, as described in 2.3.4.

\subsubsection{Biofilm sample preparation for diuron analysis}

Diuron was extracted from biofilm matrices using Accelerated Solvent Extraction (ASE 2000, Dionex, France). A solution of surrogates was prepared with Monuron d6 (CAS: 217488-65-8) at a final concentration of $10 \mathrm{mg} \cdot \mathrm{L}^{-1}$, Prometryn d6 (CAS: 1705649-52-0) at $1 \mathrm{mg} . \mathrm{L}^{-1}$ and Simazine d5 (CAS: 220621-41-0) at $20 \mathrm{mg} \cdot \mathrm{L}^{-1}$, all provided by Dr. Ehrenstorfer GmbH. The ASE cells were filled as follows: the GF/F filter containing the lyophilized biofilm, Fontainebleau sand, and $10 \mu \mathrm{L}$ of surrogates (to control the percentage of recovery) were introduced into the ASE device. The extraction was performed at 70 bars and $100^{\circ} \mathrm{C}$, with acetone (CAS: 67-64-1, purity: $99.5 \%$, ChemLab) as the solvent. Once the extraction complete, acetone samples were evaporated under nitrogen flux with a Visiprep ${ }^{\mathrm{TM}}$ (Supelco) and the extracted pesticides were dissolved in $10 \mathrm{~mL}$ of ultrapure water (Synergy UV, Millipore).

Samples were purified by Solid Phase Extraction (SPE) on HR-X Chromabond cartridges (MachereyNagel, Germany) previously conditioned with $5 \mathrm{~mL}$ of methanol (CAS: $67-56-1$, purity: $99.95 \%$, 
Biosolve) and $5 \mathrm{~mL}$ of ultrapure water. Samples were percolated through the cartridge, then the cartridge was rinsed with $20 \%$ - $80 \%$ methanol (CAS: 67-56-1, purity: $99.95 \%$ ) -ultrapure water buffer, and dried in a vacuum with a Visiprep ${ }^{\mathrm{TM}}$ for 30 minutes. The cartridges were eluted with $5 \mathrm{~mL}$ of acetonitrile (CAS: $75-05-8$, purity: $99.97 \%$ ), and $10 \mu \mathrm{L}$ of internal standard were added to the eluate collected. The mixture was evaporated until dry in a SpeedVac (Thermo Fisher Scientific, France), and the extracted diuron was dissolved into $1 \mathrm{~mL}$ of ultrapure water before analysis (2.3.4).

\subsubsection{Diuron quantification in water and biofilm}

Diuron and its main metabolites (DCPMU and DCPU) in biofilms and water samples were quantified by UPLC-ToF (Ultra-Performance Liquid Chromatography - Time of Flight Mass Spectrometry, Xevo G2-S ToF, Waters) as proceeded in a previous study (see Chaumet et al., 2019). An ACQUITY BEH C18 column $50 \times 2.1 \mathrm{~mm}, 1.7 \mu \mathrm{m}$ (Waters) was used for chromatographic separation at $45^{\circ} \mathrm{C}$ with a binary gradient of ultrapure water $(\mathrm{at} \mathrm{pH}=5)$ and methanol (both solutions with ammonium acetate to a concentration of $10 \mathrm{mM}$, CAS: 631-61-8, ULC quality Biosolve), and $20 \mu \mathrm{L}$ of samples were injected. The gradient was performed with the following range: $98 \%$ of ultra-pure water solution (0-3.6 min), $2 \%$ of methanol solution (3.6-6 $\mathrm{min}$ ) at a flow rate of $0.45 \mathrm{~mL} \cdot \mathrm{min}^{-1}$.

Data were processed with MassLynx V4.1 software, and diuron concentrations were inferred via a calibration curve from 0 to $100 \mu \mathrm{g} \cdot \mathrm{L}^{-1}$, comprising 10 points. Every 10 samples, 3 quality controls were carried out at 0,1 and $10 \mu \mathrm{g} \cdot \mathrm{L}^{-1}$ on the calibration curve. For biofilm samples, data were normalized by dry weight and then expressed in $\mu \mathrm{g} \cdot \mathrm{g}^{-1}$. Limits of quantification were established at 5 $\mu \mathrm{g} \cdot \mathrm{L}^{-1}$ for water samples and at $0.05 \mu \mathrm{g} \cdot \mathrm{mg}^{-1}$ for biofilm samples.

\subsection{Biofilm characterization}

\subsubsection{Polysaccharide analysis}


Polysaccharide content was analysed according to the method outlined by Dubois et al. (1956).Aliquots of $500 \mu \mathrm{L}$ of samples were prepared by adding $12.5 \mu \mathrm{L}$ of phenol (CAS: 108-95-2, purity: $99 \%$, Scharlab) and $2.5 \mathrm{~mL}$ of sulfuric acid (CAS: 7664-93-9, purity: $95 \%$, VWR). Samples were incubated at room temperature for 10 minutes, and then 20 minutes in a water bath at $30^{\circ} \mathrm{C}$. Absorbance was read with a microplate reader (Synergy ${ }^{\mathrm{TM}} \mathrm{HT}$, Biotek, USA) at $485 \mathrm{~nm}$. Absorbance data were converted into $\mu \mathrm{g}$ glucose-equivalent per $\mathrm{cm}^{2}$ using a standard curve of $\mathrm{D}(+)-$ glucose anhydrous solution (CAS: 50-99-7, ACS Reagent Grade, Scharlab) from 0 to $750 \mu \mathrm{g} \cdot \mathrm{L}^{-1}$. Concentrations were expressed in percentage of $T_{0}$ values for each condition, to account for variability of the inoculums used.

\subsubsection{Protein dosage}

A protocol adapted to low concentrations of proteins was developed based on the methodology presented by Bradford (1976). An aliquot of $500 \mu \mathrm{L}$ of the suspended biofilm was collected and 4.5 $\mathrm{mL}$ of methanol were added, then the mixture was sonicated for 20 minutes. Samples were then evaporated close to dryness with a SpeedVac (Thermo Fisher Scientific, France) and filled again with $500 \mu \mathrm{L}$ of ultrapure water and $2.5 \mathrm{~mL}$ of Bradford reagent, prepared using $3.3 \mathrm{mg}$ of Brilliant blue $\mathrm{G}$ (CAS: $6104-58-1$, Sigma), $33.3 \mathrm{~mL}$ of methanol, $66.67 \mathrm{~mL}$ of phosphoric acid (CAS: 7664-38-2, purity: $85 \%$, Chem-Lab) and $900 \mathrm{~mL}$ of ultra-pure water. Samples were gently agitated to homogenize the color thus formed. Absorbance was measured using a microplate reader (Synergy ${ }^{\mathrm{TM}} \mathrm{HT}$, Biotek, USA) at $595 \mathrm{~nm}$. Protein content was determined using a standard curve from 0 to $250 \mu \mathrm{g} \cdot \mathrm{L}^{-1}$ performed with Bovine Serum Albumine (BSA, CAS: 9048-46-8, Sigma). Data obtained in $\mu \mathrm{g}$ of BSA-equivalent per $\mathrm{cm}^{2}$ were then expressed in percentage of $\mathrm{T}_{0}$ values for each condition. 
Two extracellular enzymatic activities related to the heterotrophic component of the biofilm were measured: the $\beta$-glucosaminidase (EC 3.2.1.30) and the $\beta$-glucosidase (EC 3.2.1.21) activities, carriedout according to the methodology outlined in Romaní et al. (2008). The two substrates, 4methylumbelliferyl N-acetyl- $\beta$-D-glucosaminide (CAS: 37067-30-04, Sigma) and 4-methylumbelliferyl$\beta$-D-glucopyranoside (CAS: 18997-57-4, Sigma), respectively associated to $\beta$-glucosaminidase and $\beta$ glucosidase, were prepared at a final concentration of $0.3 \mathrm{mmol} . \mathrm{L}^{-1}$ (corresponding to the saturation concentration of the substrate (Romanı et al., 2004). A $150 \mu \mathrm{L}$ volume of substrate was added to 150 $\mu \mathrm{L}$ of sample aliquot, away from light. Samples were incubated under agitation ( $80 \mathrm{rpm}$, Orbitron, Infors $\mathrm{HT}$ ) during one hour in the dark. The reaction was stopped with $5 \mathrm{~mL}$ of glycine and $\mathrm{NaOH}$ buffer, made with $803.5 \mathrm{~mL}$ of $\mathrm{NaOH}$ (CAS: $1310-73-2$, purity: $98 \%$, Sigma-Aldrich) solution at 8 g.L ${ }^{-1}$ and $196.5 \mathrm{~mL}$ of a glycine (CAS: 17-1323-01, purity: $99.7 \%$, GE-healthcare - Life sciences) solution at 75.04 g. $^{-1}$. Fluorescence was measured with a microplate reader (Synergy ${ }^{\mathrm{TM}} \mathrm{HT}$, Biotek, USA) at excitation-emission wavelengths of $365-455 \mathrm{~nm}$. A standard curve was performed with 7-Hydroxy-4methylcoumarin (MUF, CAS: 90-33-5, purity: $97 \%$, Acros Organics) from 0 to $50000 \mu \mathrm{g}$ MUF. $\mathrm{L}^{-1} \cdot \mathrm{h}^{-1}$ and was used to calculate the percentage of enzymatic activities in comparison with $T_{0}$ values for each condition.

\subsubsection{Photosynthetic activity measurement}

Photosynthetic activity (effective photosystem II quantum yield, $\Phi_{\text {PSII }}$ ) of all samples was assessed by chlorophyll $a$ fluorescence measurement with a Pulse Amplitude Modulated fluorimeter (PhytoPAM, Heinz Walz GmbH, Germany) in quartz cuvettes (Emitter-Detector Unit PHYTO-ED). Five replicate measurements per sample were performed on biofilm suspensions after 15 minutes of light adaptation. Every sample was measured with a Photosynthetic Active Radiation of $164 \mu \mathrm{mol} . \mathrm{m}^{-2} \cdot \mathrm{s}^{-1}$ in Actinic Light mode. 
Data obtained were not normal and different conditions tested were independent, consequently, non-parametric tests were applied. The aim of the statistical analysis was to highlight if they were significant differences between conditions tested like between the two temperatures, or the two photoperiods, or the three exposure concentrations, or time exposure. A Kruskal-Wallis test followed by a posthoc kruskalmc test [Package pgirmess version 3.6.1] were performed on data from all the analyses (in percentage of $T_{0}$ ), and then on each biological descriptor individually. A p-value of 0.05 was considered significant. A linear discriminant analysis was applied on the same dataset (in percentage of $\mathrm{T}_{0}$ ) with $\mathrm{R}$ software [Package ade4 version 1.6-2], with the aim of individualising data into similarly-composed groups.

\section{Results}

\subsection{Seasonal condition effects on control samples}

251

The dry weight of the biofilm samples measured immediately after collection from the pond $\left(T_{0}\right)$ for each season showed high variations. Indeed, biomass regularly increased between S1 and S4, with values 6-fold higher at S4 than S1 $\left(D W_{S 1}=33 \pm 5 \mu \mathrm{g} \cdot \mathrm{cm}^{-2}\right.$ and $D W_{S 4}=203 \pm 27 \mu g \cdot \mathrm{cm}^{-2}, T_{a b l e ~ 2)}$ highlighting that biofilm colonisation depends on the period of the year (meteorological parameters) in temperate settings. It was observed that the biomass in the inoculum can vary greatly from one sample to another. Therefore, the results obtained for the structural and functional descriptors were standardized by the associated $T_{0}$, thus avoiding biomass bias. The samples could then be compared with each other at the level of absolute variations observed after exposure. Variations between dates and diuron exposure treatments were expressed as percentages of $T_{0}$, to highlight only the effect of temperature, photoperiod and diuron. Biofilm dry weight generally increased over the three days of channel exposure, and the 3-day increase in biomass was little more pronounced at $26^{\circ} \mathrm{C}$. In fact, for season 1 and 2, the growth rate was of 0.68 and $0.69 \mu \mathrm{g} \cdot \mathrm{cm}^{-2} \cdot \mathrm{h}^{-1}$ respectively $(2.5$ times increase in 3 
days for S1 and 1.9 times greater for S2, Table 2) and of 0.4 and -0.4 for season 3 and 4 respectively

264 (1.4 times increase in 3 days for S3, Table 2). Even, a slight decrease in dry weight was visible after

265 three days of exposure for S4. On the other hand, in terms of photosynthetic yield of the control

266 samples, there were no marked effects of temperature nor of photoperiod, whatever the exposure time.

Protein dosage and $\beta$-glucosidase activity measurement showed an increase in percentage at three days compared to $T_{0}$ (Table SI 1 and Figure 2). The same trend was visible for polysaccharide results and $\beta$-glucosaminidase activity measurements, but only for biofilms exposed to $26^{\circ} \mathrm{C}$. For these descriptors, samples exposed to $10^{\circ} \mathrm{C}$ did not highlight any particular variation (around $100 \% \mathrm{~T}_{0}$ ).
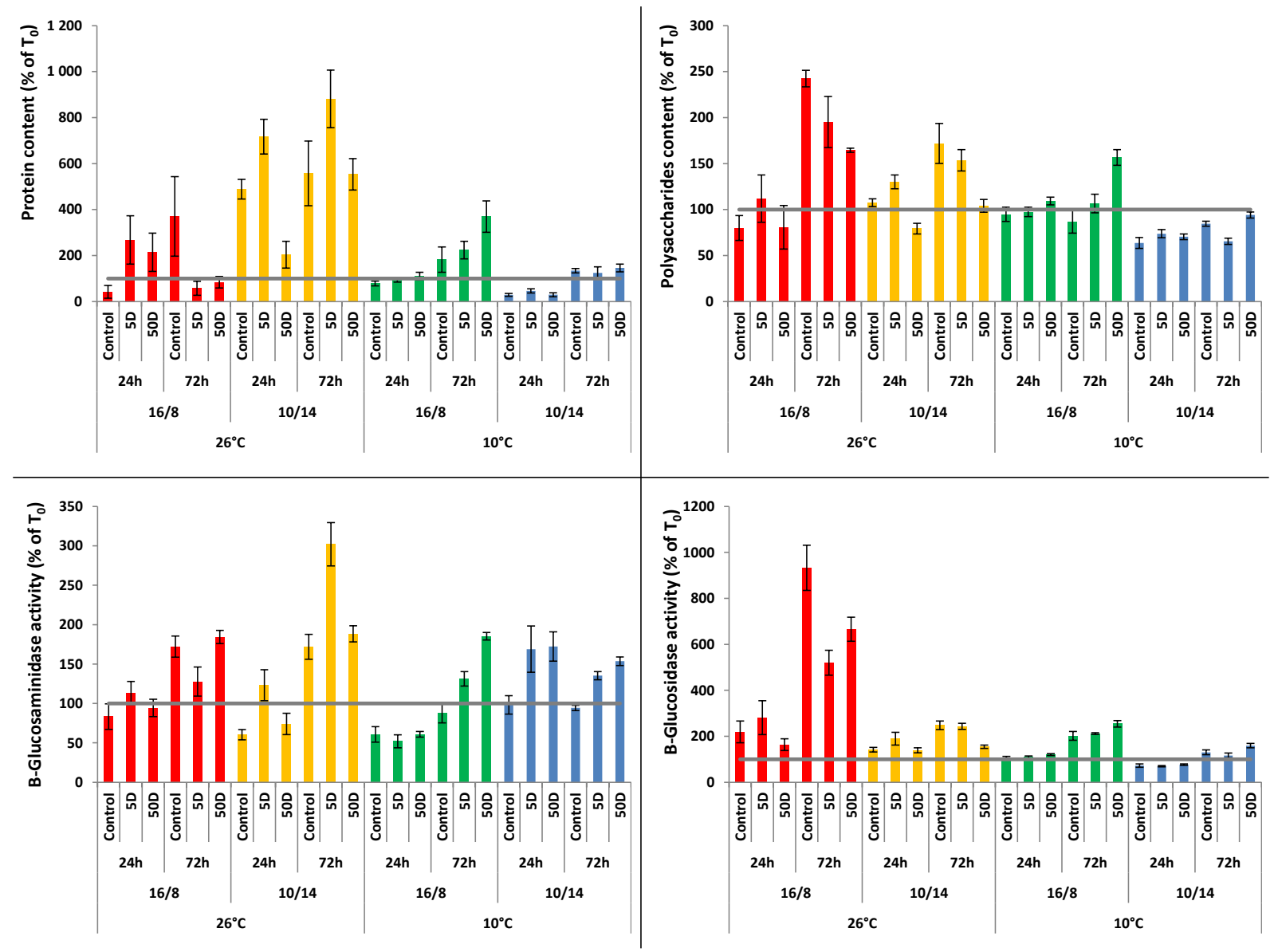

Figure 2: Polysaccharide and protein contents, and $\beta$-Glucosaminidase and $\beta$-Glucosidase activities (mean $\pm s d, n=4$ ) in percentage of $T_{0}$ (grey line: $100 \%$ of $T_{0}$ value for each condition). The conditions 
are differentiated as follows: Season 1 in red, Season 2 in yellow, Season 3 in green, and Season 4 in blue.

Generally, for all descriptors, results highlighted an evolution between $T_{0}$, one day and three days of exposure, with results slightly more marked after three days. For data collected after three days of exposure, the temperature effect was noticeable for all descriptors (Table SI 1 and Figure 2). Nevertheless, data were not statistically different but they allow to highlight a trend because all showed an increase of percentage in comparison to $T_{0}$ for samples exposed to $26^{\circ} \mathrm{C}$. There were almost no differences between conditions for $\beta$-glucosaminidase activity among the different photoperiods. However, $\beta$-glucosidase activity was slightly affected by the most extended photoperiod independently of the temperature after three days of exposure. Indeed, we observed an increase of this enzymatic activity with the longer photoperiod (e.g. S1 was 3.8 times higher than S2 and S3 1.6 greater than S4, Figure 2, Table SI1). The same trend was visible for polysaccharide percentage, but more moderately, also for protein percentage but only between S3 and S4.

Table 2: Mean $( \pm \mathrm{sd})$ dry weight in $\mu \mathrm{g} \cdot \mathrm{cm}^{-2}$ and photosynthetic yield in Ctrl biofilms. ${ }^{*}$ indicates significant differences within the conditions (Kruscalmc test)

\begin{tabular}{|l|l|l|l|}
\hline $\begin{array}{l}\text { Conditions } \\
\text { (temperature, photoperiod) }\end{array}$ & $\begin{array}{l}\text { Exposure time } \\
(\text { day) }\end{array}$ & Mean dry weight $\left(\mu \mathrm{g} \cdot \mathrm{cm}^{-2}\right)$ & Photosynthetic yield \\
\hline \multirow{3}{*}{ Season 1} & 0 & $33 \pm 5$ & $0.41 \pm 0.02$ \\
\cline { 2 - 4 }$\left(26^{\circ} \mathrm{C}, 16 / 8\right)$ & 1 & $35 \pm 6$ & $0.48 \pm 0.02$ \\
\cline { 2 - 4 } & 3 & $83 \pm 10$ & $0.49 \pm 0.02$ \\
\hline \multirow{3}{*}{ Season 2 } & 0 & $57 \pm 10$ & $0.44 \pm 0.02$ \\
\hline$\left(26^{\circ} \mathrm{C}, 10 / 14\right)$ & 1 & $65 \pm 11$ & $0.51 \pm 0.03$ \\
\cline { 2 - 4 } & 3 & $106 \pm 18$ & $0.51 \pm 0.01$ \\
\hline
\end{tabular}




\begin{tabular}{|l|l|l|l|}
\hline \multirow{3}{*}{ Season 3} & 0 & $79 \pm 10$ & $0.50 \pm 0.01$ \\
\cline { 2 - 4 }$\left(10^{\circ} \mathrm{C}, 16 / 8\right)$ & 1 & $87 \pm 11$ & $0.55 \pm 0.01^{*}$ \\
\cline { 2 - 4 } & 3 & $107 \pm 13$ & $0.54 \pm 0.01^{*}$ \\
\hline \multirow{3}{*}{ Season 4} & 0 & $203 \pm 27$ & $0.53 \pm 0.01$ \\
\hline$\left(10^{\circ} \mathrm{C}, 10 / 14\right)$ & 1 & $139 \pm 27$ & $0.51 \pm 0.01$ \\
\cline { 2 - 4 } & 3 & $175 \pm 34$ & $0.51 \pm 0.01$ \\
\hline
\end{tabular}

292 About biofilm characterization, temperature and photoperiod had an influence on structural biofilm parameters. For biofilms exposed to the highest temperature $\left(26^{\circ} \mathrm{C}\right)$, polysaccharide content increased between day 1 and day 3 (Figure 2). This effect was considerably less marked in biofilms exposed at a temperature of $10^{\circ} \mathrm{C}$ than at $26^{\circ} \mathrm{C}$. In general, the polysaccharide percentage from control treatments increased in the following order: $\mathrm{S} 4<\mathrm{S} 3<\mathrm{S} 2<\mathrm{S} 1$. This result resembles that observed for other descriptors, like protein content and enzymatic activities. At equal temperature, polysaccharide concentrations were higher with a longer photoperiod (S2 $<\mathrm{S} 1, \mathrm{~S} 4<\mathrm{S} 3$ ).

Diuron concentration in the water channels was quantified at $5.1 \pm 0.2(n=4)$ and $43.9 \pm 0.4 \mu \mathrm{g} \cdot \mathrm{L}^{-1}(n=$ 4) of diuron, respectively, for 5D and 50D treatments which is extremely close to nominal concentrations. The results from control water channels and metabolite concentrations in exposed channels (for water and biofilms samples) were below the limit of quantification. No statistical difference in diuron exposure for each treatment was found between conditions or dates of sampling. The concentrations of the main metabolites of diuron were below the limits of quantification 
A small amount of diuron was quantified in biofilm samples from control conditions (mean= $88.4 \pm$ $19.9 \mu \mathrm{g} . \mathrm{g}^{-1}$ of diuron) which could originate from the environment during colonisation. The total amount of diuron measured within biofilms exposed to $10^{\circ} \mathrm{C}$ was globally higher (but not significantly) than within those exposed to $26^{\circ} \mathrm{C}$ (Figure 3). This observation was more noticeable for 50D treatments. For 50D, at a given temperature of exposure, bioaccumulation tended to be higher when light exposure time increased.

In general, the results presented in Figure 2 did not show very marked trends in terms of the effect of diuron on functional and structural descriptors. However, although there was no significant difference to confirm these observations, it would appear that for all descriptors, after 3 days of exposure, there was an increase with exposure concentration for biofilms exposed to $10^{\circ} \mathrm{C}$, and a slight decrease (proteins, polysaccharides, $\beta$-glucosidase activity), or a stability ( $\beta$-glucosaminidase activity) for biofilms exposed to $26^{\circ} \mathrm{C}$.

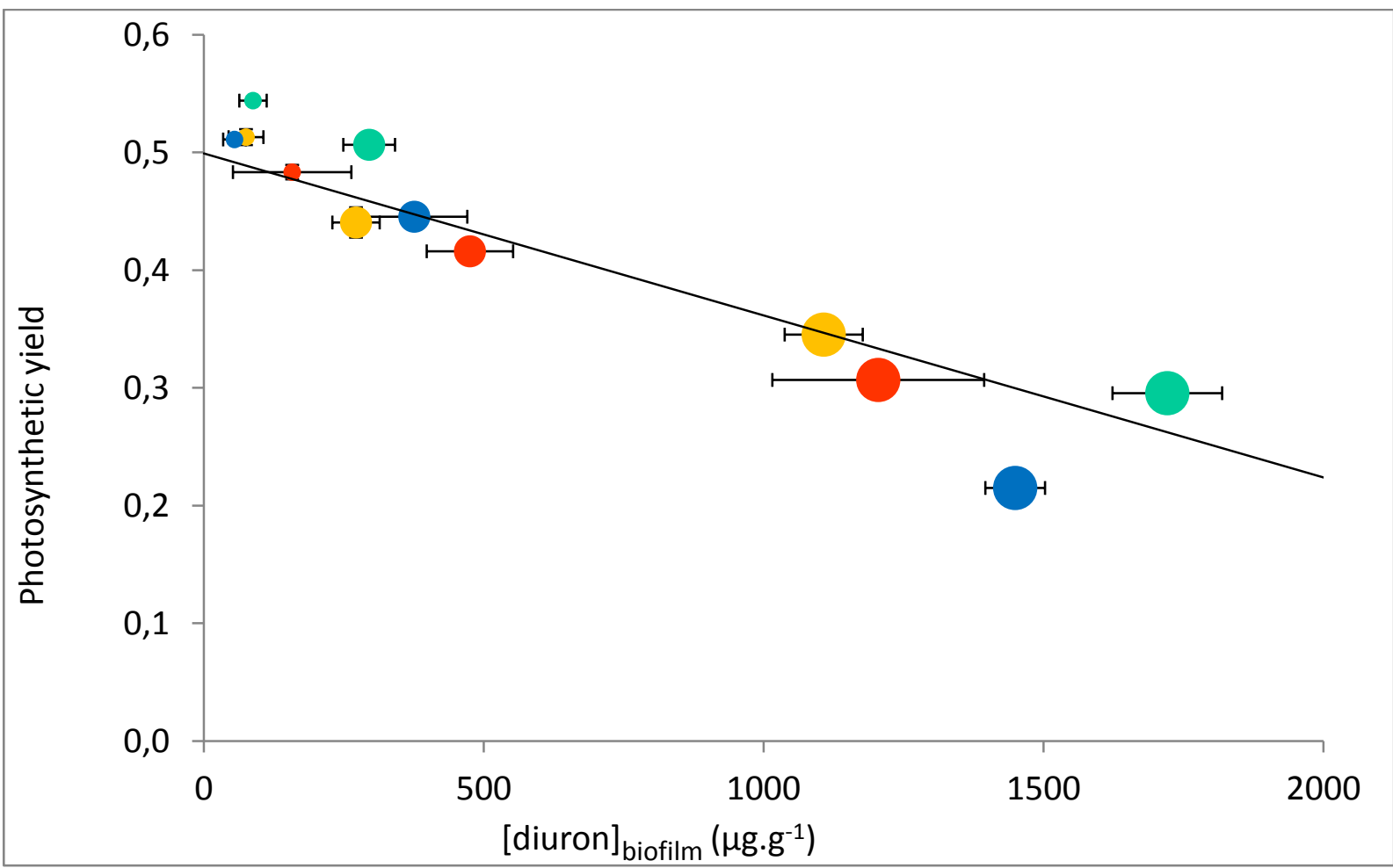

Figure 3: Mean photosynthetic quantum yield ( $\pm s d, n=4)$ as a function of diuron bioaccumulation in the biofilm in $\mu \mathrm{g} \cdot \mathrm{g}^{-1}$ (mean $\left.\pm \mathrm{sd}\right)$, for biofilms exposed in channels during one and three days. The 
conditions are differentiated as follows: Season 1 in red, Season 2 in yellow, Season 3 in green, and Season 4 in blue. The black line represents the linear regression performed on the whole dataset. The size of the points is proportional to the dose of exposure (small $=C$ trl, middle $=5 \mathrm{D}$, large $=50 \mathrm{D})$.

The effects of temperature on toxicity were not as clear as on bioaccumulation. Indeed, the photosynthetic yield was lower at $10^{\circ} \mathrm{C}$ for the $50 \mathrm{D}$ treatment and at $26^{\circ} \mathrm{C}$ for the $5 \mathrm{D}$ treatment (Figure 3, also see Table SI2 in the Supplementary Material). However, at $10^{\circ} \mathrm{C}$ the photosynthetic yield tended to decrease with the luminosity amplitude ( $\mathrm{S} 4<\mathrm{S} 3$ ), and at $26^{\circ} \mathrm{C}$, the contrary was observable, but the photosynthetic yields were quite close between S1 and S2. Photosynthetic activity was negatively correlated with diuron bioaccumulation in the biofilm $\left(R^{2}=0.684, p\right.$-value $<$ 0.001; Figure 3), correlation coefficients calculated for each condition separately increased as follow: S1 $\left(R^{2}=0.48, p\right.$-value $\left.<0.001\right)<$ S2 $\left(R^{2}=0.52, p\right.$-value $\left.<0.001\right)<S 3\left(R^{2}=0.87\right.$, p-value $\left.<0.001\right)<S 4\left(R^{2}=\right.$ 0.94, p-value< 0.001) (see Figure SI 1).

\subsection{Influence of environmental variation on metabolism}

The Kruskalmc test performed on data from all analyses did not show significant differences according to temperature, photoperiod or diuron effect. It was subsequently performed with data from each descriptor, and there were no significant trends with regard to the different environmental exposure conditions and contaminations. The linear discriminant analysis carried out with structural descriptors (proteins, polysaccharides) and enzymatic activities, after three days of exposure, all treatments combined (as diuron had no effect on these descriptors), discriminated the different conditions.

Seasons 1 and 2 were separated along axis 1 (Figure 4), which was mostly explained by an increasing relative activity of $\beta$-glucosidase ("BetaGlu"; mean of three days for all treatments $\mathrm{S} 1=706 \%$ and S2= $215 \%)$. In fact, conditions were discriminated along this axis in relation to the $\beta$-glucosidase activity 
as follows: $\mathrm{S} 2<\mathrm{S} 4<\mathrm{S} 3<\mathrm{S} 1$. Thus, axis 1 highlighted photoperiod influence on biological responses, mainly related to the amplitude of variation in $\beta$-glucosidase activity over three days. Season 2 was also characterized by a slightly higher relative protein content and $\beta$-glucosaminidase activity, and Season 1 by slightly higher polysaccharide content and $\beta$-glucosidase activity. In contrast to the conditions presenting higher temperatures, Seasons 3 and 4 were anticorrelated with Seasons 1 and 2 along axis 2, due to their slightly lower polysaccharide content. Axis 2 discriminated seasons according to temperature as follows: $\mathrm{S} 2<\mathrm{S} 1<\mathrm{S} 3<\mathrm{S} 4$.

Additionally, the fact that conditions sharing a seasonal characteristic (equal temperature or photoperiod) were not fully identical suggests an interaction between the influence of temperature and photoperiod. These results highlight the influence of photoperiod and temperature on biofilm metabolism and illustrate the previous conclusions that these factors influenced the variation over three days in polysaccharide and protein content, as well as in $\beta$-glucosaminidase activity over three days (section 3.1).

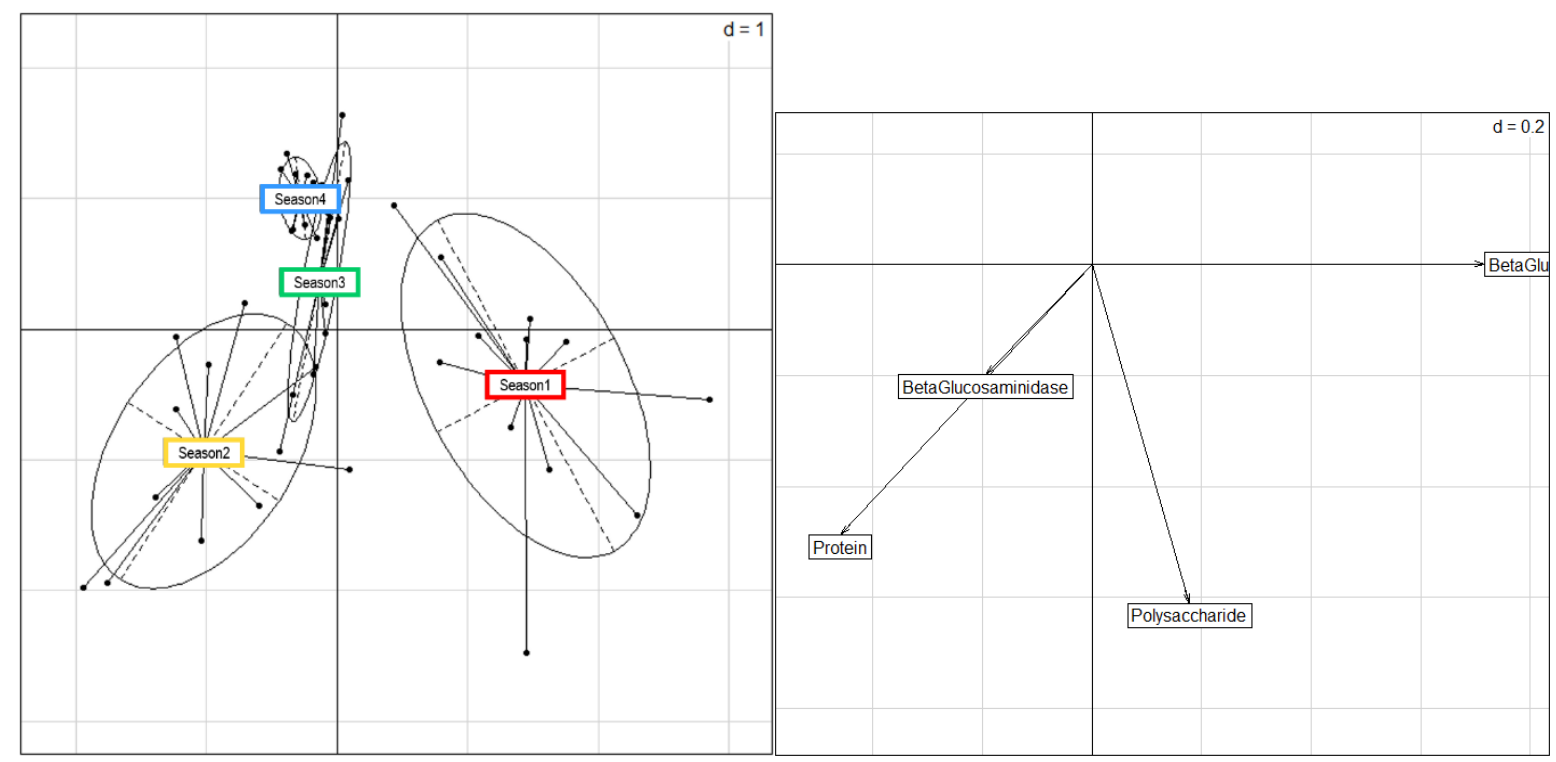

Figure 4: Linear discriminant analysis of the different conditions after three days of exposure (left panel) based on polysaccharide and protein content, and extracellular enzymatic activities (right panel). 


\section{Discussion}

\subsection{Diuron impact on PSII}

371

The results show that diuron bioaccumulation in biofilm was higher at $10^{\circ} \mathrm{C}$ than at $26^{\circ} \mathrm{C}$ (e.g. $27 \%$ more at $10^{\circ} \mathrm{C}$ ) except for $\mathrm{S} 1$ with $5 \mathrm{D}$ treatment, and consequently, the photosynthetic activity was more inhibited at $10^{\circ} \mathrm{C}$ for associated samples, at equal photoperiods (Figure 3). Toxic effects observed in this study are in accordance with many others carried out on similar microorganisms (green algae, diatoms) with pesticides. For example, Tasmin et al. (2014) found a 12-17 \% increase of photosynthesis inhibition on microalgae with a decrease in temperature from 25 to $10^{\circ} \mathrm{C}$ for a contamination at $32 \mu \mathrm{g} . \mathrm{L}^{-1}$ of diuron during three days. These observations are in accordance with our results: an increase of $16 \%$ of photosynthesis inhibition with a decrease in temperature. Moreover, Chalifour et al. (2014) measured a photosynthetic yield decrease from 57 to $98 \%$ between 25 and $15^{\circ} \mathrm{C}$ in green algae exposed to $2.5 \mu \mathrm{M}$ of norflurazon (a herbicide). Although the literature dealing with combined herbicide and temperature impacts on photosynthetic yield is abundant, there is very little information on bioaccumulation aspects. This work complements the existing knowledge by showing that higher PSII inhibition at lower temperatures is likely explained by higher amounts of accumulated diuron.

\subsection{Metabolism variations with temperature and light}

\section{Environmental modulation effect}


Heterotrophic organisms were not accurately identified, however, the choice of the dosage of the two enzymatic activities allowed to provide information on the activity of the heterotrophic component of the biofilm. Indeed, $\beta$-glucosaminidase plays a role in the degradation of peptidoglycans (a component of the bacterial wall) and chitin (a polysaccharide derived from fungal walls), and $\beta$-glucosidase is involved in carbohydrate degradation. In our study, the linear discriminant analysis highlighted that $\beta$-glucosidase activity was boosted by longer periods of light, and the contrary for $\beta$-glucosaminidase activity, both at higher temperatures. This means that the metabolism of organisms such as bacteria and fungi were intensively activated at $26^{\circ} \mathrm{C}$, indicating a favourable environment for them (Lurling et al., 2012).

For autotrophic organisms, photosynthetic activity is directly related to metabolism, itself dependent on temperature (Brown et al., 2004). In this study, polysaccharide quantities produced after three days of exposure were greater at $26^{\circ} \mathrm{C}$ than at $10^{\circ} \mathrm{C}$, suggesting that the biofilm was less productive at colder temperatures. These results are in accordance with those of Wolfstein and Stal (2002) who found a slight increase (around 1.25 - 1.3 times higher) in EPS content (composed of polysaccharides and proteins) after three and nine days of exposure between biofilm exposed from $10^{\circ} \mathrm{C}$ to $25^{\circ} \mathrm{C}$, with a photoperiod of 12/12.

\section{Interaction of environmental factors effects with the impact of diuron}

The effects of environmental factors interacting with diuron were not clearly visible and not significant on heterotrophic organisms. In fact, as diuron is a photosynthetic inhibitor herbicide, it should have a greater influence on autotrophic compartment. Results for $\beta$-glucosaminidase activity showed a slight decrease at $10^{\circ} \mathrm{C}$ and a stability at $26^{\circ} \mathrm{C}$ after three days of exposure between controls and the most contaminated condition. In contrary $\beta$-glucosidase activity was marked by a small increase. Indeed, diuron is a photosynthetic inhibitor herbicide, so it does not directly target bacteria and fungi over such short periods of exposure as strongly as microalgae and their 
photosynthetic capacity. Because of the very short duration of biofilm exposure (three days), the

414 toxic effect of these factors may not have reached the whole community through cascading effects

415 (Proia et al., 2012). The same phenomenon was found by Proia et al. (2011), who observed that after

416 two days of exposure to diuron at $15 \mu \mathrm{g} \cdot \mathrm{L}^{-1}$, the bacteria showed no structural nor functional

417 changes. However, following this exposure and during one week of recovery, they observed indirect

418 effects such as a transient increase in bacterial mortality.

419 However, this study, combining toxicokinetic and toxicodynamic approaches, showed the evolution

420 of the effects of environmental factors and diuron on biofilm metabolism over time. Although the

421 data showed little difference over a three-day period exposure, they still highlight an evolution and a

422 dynamic system, suggesting a greater impact on longer-term exposure in the natural environment.

423 Although our results showed no significant differences between conditions, the effect of diuron on

424 algae seemed to be modulated by temperature and light to variable extents, depending on the

425 concentration of exposure. Nevertheless, the results showed that among all the descriptors analysed,

426 the only part of the metabolism significantly impacted by diuron was photosynthetic activity.

427 Contrastingly, polysaccharide and protein production and enzymatic activities were mainly affected

428 by the interaction between temperature and photoperiod (Figure 2).

429 Overall, biofilm appeared to be less impacted and more productive at $26^{\circ} \mathrm{C}$ than at $10^{\circ} \mathrm{C}$. This can be 430 explained by the fact that the biofilm originated from conditions close to Season $4\left(10^{\circ} \mathrm{C}\right.$, light/dark 431 cycle of 10/14). A priori, the biofilms having experienced the highest degree of disturbance should be 432 the ones from S1, with a drastic change in environmental conditions $\left(+6 \mathrm{~h}\right.$ of light $/$ day and $\left.+16^{\circ} \mathrm{C}\right)$. As 433 conditions in S1 seem to be favourable to the activation of metabolism, this could explain the high 434 polysaccharide and protein production under the conditions of this treatment. That means that even 435 if the change of environmental conditions can affect the biofilms (e.g. from around $10^{\circ} \mathrm{C}$ in the pond 436 to $26^{\circ} \mathrm{C}$ in the channels), it appears that this case the increase of temperature and photoperiod 
duration is not the most impacting external stress like cold temperature and dark/light cycle 438 reduced.

Indeed, in the case of stressful conditions, organisms can slow their metabolism in order to reduce their energy needs (Brown et al., 2004). The results of Chalifour et al. (2014) support this fact by

441 showing that algae use their energy reserves to maintain a growth rate similar to controls in the

442 presence of herbicide ( $2.5 \mu \mathrm{M}$ norflurazon) and over 4 days, they observed a strong decrease in 443 photosynthetic efficiency. Our results present the same kind of phenomenon for contaminated 444 conditions: at $26^{\circ} \mathrm{C}$ polysaccharide production was boosted, while at $10{ }^{\circ} \mathrm{C}$, production remained 445 stable. Also, photosynthetic efficiency was greater under $26^{\circ} \mathrm{C}$ exposure. All this shows that biofilm 446 exposed to low temperatures and a shorter photoperiod is forced to restrict the energy allocated for 447 its growth, hence the lower metabolic activity of the biofilm during Season 4 and its greater 448 sensitivity to diuron.

449 All the variations observed in this study on biofilm show only trends and not significant differences, 450 which begs the question of what the major changes would be that would take place over longer 451 exposure times, and at the level of community composition.

\section{Conclusion}

This study focused on the influence of interactions between diuron exposure, temperature and 455 photoperiod on pesticide bioaccumulation and toxic impact on biofilm. Our results suggest some 456 influence of temperature on bioaccumulation, and consequently on photosynthetic activity. They 457 imply that Winter biofilms in temperate regions are more sensitive to diuron exposure than Summer ones.

Our results agree with the existing literature dealing with the joint influence of temperature and herbicides on biofilm vulnerability. However, this study also demonstrates the influence of 
461

462

463

464

465

466

467

468

469

470

471

472

473

474

475

476

477

478

479

480

481

482

photoperiod duration on several biofilm endpoints, not only related to the autotrophic component of the community. Moreover, this work goes further by coupling toxicokinetic and toxicodynamic aspects, allowing to link the bioaccumulation of pesticides in biofilms with their metabolism.

\section{Acknowledgments}

This study was carried out with financial support from the French National Research Agency (ANR) in the framework of the Investments for the future Programme, within the Cluster of Excellence COTE (ANR-10-LABX-45).

\section{Conflict of interest}

The authors declare that the research was conducted in the absence of any commercial or financial relationships that could be construed as a potential conflict of interest.

\section{Bibliography}

Aguilera, A., Souza-Egipsy, V., Martín-Úriz, P. S., \& Amils, R. (2008). Extraction of extracellular polymeric substances from extreme acidic microbial biofilms. Applied Microbiology and Biotechnology, 78(6), 1079-1088. https://doi.org/10.1007/s00253-008-1390-9

Aguilera, A., Souza-Egipsy, V., San Martín-Úriz, P., \& Amils, R. (2008). Extracellular matrix assembly in extreme acidic eukaryotic biofilms and their possible implications in heavy metal adsorption. Aquatic Toxicology, 88(4), 257-266. https://doi.org/10.1016/j.aquatox.2008.04.014

Bérard, A., Leboulanger, C., \& Pelte, T. (1999). Tolerance of Oscillatoria limnetica Lemmermann to atrazine in natural phytoplankton populations and in pure culture: Influence of season and temperature. Archives of Environmental Contamination and Toxicology, 37(4), 472-479. https://doi.org/10.1007/s002449900541 
Brown, J. H., Gilloolly, J. F., Allen, A. P., Savage, V. M., \& West, G. B. (2004). Toward a metabolic theory of ecology. Ecology, 85(7), 1771-1789. https://doi.org/10.2106/JBJS.J.01311

Chalifour, A., Arts, M. T., Kainz, M. J., \& Juneau, P. (2014). Combined effect of temperature and bleaching herbicides on photosynthesis, pigment and fatty acid composition of Chlamydomonas reinhardtii. European Journal of Phycology, 49(4), 508-515. https://doi.org/10.1080/09670262.2014.977962

Chaumet, B., Morin, S., Hourtané, O., Artigas, J., Delest, B., Eon, M., \& Mazzella, N. (2019). Flow conditions influence diuron toxicokinetics and toxicodynamics in freshwater biofilms. Science of the Total Environment, 652, 1242-1251. https://doi.org/10.1016/j.scitotenv.2018.10.265

Dauta, A. (1982). Conditions de développement du phytoplancton. Etude comparative du comportement de huit espèces en culture. II. Rôle des nutriments : assimilation et stockage intracellulaire. Annales de Limnologie, 18(3), 263-292. https://doi.org/10.1051/limn/1982014

DeLorenzo, M. E., Scott, G. I., \& Ross, P. E. (2001). Toxicity of pesticides to aquatic microorganisms: a review. Environmental Toxicology and Chemistry / SETAC, 20(1), 84-98. https://doi.org/10.1002/etc.5620200108

Dodds, W. K., Hutson, R. E., Eichem, A. C., Evans, M. A., Gudder, D. A., Fritz, K. M., \& Gray, L. (1996). The relationship of floods, drying, flow and light to primary production and producer biomass in a prairie stream. Hydrobiologia, 333(3), 151-159. https://doi.org/10.1007/BF00013429

Draber, W., Tietjen, K., Kluth, J. F., \& Trebst, A. (1991). Herbicides in Photosynthesis Research. Angewandte Chemie International Edition in English, 30(12), 1621-1633. https://doi.org/10.1002/anie.199116211 
Dubois, M., Gilles, K. A., Hamilton, J. K., Rebers, P. A., \& Smith, F. (1956). Colorimetric Method for Determination of Sugars and Related Substances. Analytical Chemistry, 28(3), 350-356. https://doi.org/10.1021/ac60111a017

Duong, T. T., Morin, S., Coste, M., Herlory, O., Feurtet-Mazel, A., \& Boudou, A. (2010). Experimental toxicity and bioaccumulation of cadmium in freshwater periphytic diatoms in relation with biofilm maturity. Science of the Total Environment, 408(3), 552-562. https://doi.org/10.1016/j.scitotenv.2009.10.015

Edwards, S. J., \& Kjellerup, B. V. (2013). Applications of biofilms in bioremediation and biotransformation of persistent organic pollutants, pharmaceuticals/personal care products, and heavy metals. Applied Microbiology and Biotechnology, 97(23), 9909-9921. https://doi.org/10.1007/s00253-013-5216-z

Flemming, H.-C., Neu, T. R., \& Wozniak, D. J. (2007). The EPS matrix: The "House of Biofilm Cells." Journal of Bacteriology, 189(22), 7945-7947. https://doi.org/10.1128/JB.00858-07

Flemming, H.-C., \& Wingender, J. (2010). The biofilm matrix. Nature Reviews Microbiology, 8(9), 623633. https://doi.org/10.1038/nrmicro2415

Gomes, M. P., \& Juneau, P. (2017). Temperature and Light Modulation of Herbicide Toxicity on Algal and Cyanobacterial Physiology. Frontiers in Environmental Science, 5(August), 1-17. https://doi.org/10.3389/fenvs.2017.00050

Guasch, H., Artigas, J., Bonet, B., Bonnineau, C., Canals, O., Corcoll, N., Foulquier, A., López-Doval, J., Kim-Tiam, S., Morin, S., Navarro, E., Pesce, S., Proia, L., Salvadó, H., \& Serra, A. (2016). The use of biofilms to assess the effects of chemicals on freshwater ecosystems. In A. M. Romaní, H. Guasch, \& D. Balaguer (Eds.), Aquatic biofilms: Ecology, Water Quality and Wastewater Treatment (Vol. 53, p. 160). Caister Academic Press. https://doi.org/10.1017/СВ09781107415324.004 
Herzig, R., \& Dubinsky, Z. (1992). Photoacclimation, photosynthesis, and growth in phytoplankton. Israel Journal of Botany, 41(4-6), 199-212. https://doi.org/10.1080/0021213X.1992.10677227

Kim Tiam, S., Fauvelle, V., Morin, S., \& Mazzella, N. (2016). Improving toxicity assessment of pesticide mixtures: The use of polar passive sampling devices extracts in microalgae toxicity tests. Frontiers in Microbiology, 7, 1388. https://doi.org/10.3389/fmicb.2016.01388

Kim Tiam, S., Laviale, M., Feurtet-Mazel, A., Jan, G., Gonzalez, P., Mazzella, N., \& Morin, S. (2015). Herbicide toxicity on river biofilms assessed by pulse amplitude modulated (PAM) fluorometry. Aquatic Toxicology, 165, 160-171. https://doi.org/10.1016/j.aquatox.2015.05.001

Kohusova, K., Havel, L., Vlasak, P., \& Tonika, J. (2011). A long-term survey of heavy metals and specific organic compounds in biofilms, sediments, and surface water in a heavily affected river in the Czech Republic. Environmental Monitoring and Assessment, 174(1-4), 555-572. https://doi.org/10.1007/s10661-010-1478-4

Larras, F., Lambert, A., Pesce, S., Rimet, F., Bouchez, A., \& Montuelle, B. (2013). The effect of temperature and a herbicide mixture on freshwater periphytic algae. Ecotoxicology and Environmental Safety, 98, 162-170. https://doi.org/10.1016/j.ecoenv.2013.09.007

Lurling, M., Eshetu, F., Faassen, E., Kosten, S., \& Huszar, V. (2012). Comparison of cyanobacterial and green algal growth rates at different temperatures. Freshwater Biology. https://doi.org/10.1111/j.1365-2427.2012.02866.x

Pesce, S., Bouchez, A., \& Montuelle, B. (2011). Effects of Organic Herbicides on Phototrophic Microbial Communities in Freshwater Ecosystems. Reviews of Environmental Contamination and Toxicology, 214, 87-124. https://doi.org/10.1007/978-1-4614-0668-6

Proia, L., Morin, S., Peipoch, M., Romaní, A. M., \& Sabater, S. (2011). Resistance and recovery of river biofilms receiving short pulses of Triclosan and Diuron. Science of the Total Environment, 
555

556

557

558

559

560

561

562

563

564

565

566

567

568

569

570

571

572

573

574

575

576

Proia, Lorenzo, Cassió, F., Pascoal, C., Tlili, A., \& Romaní, A. M. (2012). The Use of Attached Microbial Communities to Assess Ecological Risks of Pollutants in River Ecosystems: The Role of Heterotrophs. The Handbook of Environmental Chemistry, 19, 55-83.

Romaní, A. M., Fund, K., Artigas, J., Schwartz, T., Sabater, S., \& Obst, U. (2008). Relevance of polymeric matrix enzymes during biofilm formation. Microbial Ecology, 56(3), 427-436. https://doi.org/10.1007/s00248-007-9361-8

Romanı, A., Giorgi, A., Acuna, V., \& Sabater, S. (2004). Romani et al 2004- The influence of substratum type and nutrient supply on biofilm organic matter utilization in streams- $L$ and O.pdf. Limnol. Oceanogr, 49(5), 1713-1721.

Staehr, P., \& Sand-Jensen, K. (2006). Seasonal changes in temperature and nutrient control of photosynthesis, respiration and growth of natural phytoplankton communities. Freshwater Biology, 51(2), 249-262. https://doi.org/10.1111/j.1365-2427.2005.01490.x

Tasmin, R., Shimasaki, Y., Tsuyama, M., Qiu, X., Khalil, F., Okino, N., Yamada, N., Fukuda, S., Kang, I. J., \& Oshima, Y. (2014). Elevated water temperature reduces the acute toxicity of the widely used herbicide diuron to a green alga, Pseudokirchneriella subcapitata. Environmental Science and Pollution Research, 21(2), 1064-1070. https://doi.org/10.1007/s11356-013-1989-y

Tlili, A., Dorigo, U., Montuelle, B., Margoum, C., Carluer, N., Gouy, V., Bouchez, A., \& Bérard, A. (2008). Responses of chronically contaminated biofilms to short pulses of diuron. An experimental study simulating flooding events in a small river. Aquatic Toxicology, 87(4), 252263. https://doi.org/10.1016/j.aquatox.2008.02.004

Villeneuve, A., Montuelle, B., \& Bouchez, A. (2010). Influence of slight differences in environmental conditions (light, hydrodynamics) on the structure and function of periphyton. Aquatic 
578

579

580

581

582

583

584

585

586
Villeneuve, Aurélie, Bouchez, A., \& Montuelle, B. (2011). In situ interactions between the effects of season, current velocity and pollution on a river biofilm. Freshwater Biology, 2245-2259. https://doi.org/10.1111/j.1365-2427.2011.02649.x

Wolfstein, K., \& Stal, L. J. (2002). Production of extracellular polymeric substances (EPS) by benthic diatoms: Effect of irradiance and temperature. Marine Ecology Progress Series, 236, $13-22$. https://doi.org/10.3354/meps236013

Yebra, D. M., Kiil, S., \& Dam-Johansen, K. (2004). Antifouling technology - Past, present and future steps towards efficient and environmentally friendly antifouling coatings. Progress in Organic Coatings, 50(2), 75-104. https://doi.org/10.1016/j.porgcoat.2003.06.001 